\title{
Going by the book: the Baedeker guide
}

'Kings and governments may err, but never Mr Baedeker’. (AP Herbert, 1929)

Once Napoleon had been removed from the scene in 1815, hordes of travellers descended on the roads of Europe, which had been greatly improved by the armies under his command. Their vehicle of choice was the diligence or public stagecoach, which allowed travellers not quite wealthy enough to afford their own landau a means of getting down to Italy, or even up to the mountains of Switzerland, which after centuries of being viewed as the whims or monstrosities of nature had suddenly become fashionable.

On their lap, these lone travellers would have a red Baedeker volume. His aim, he stated, was to protect the traveller from unwanted molesters, touts, and undesirables, 'to render him independent, and to place him in a position from which he may receive his own impressions with clear eyes and lively heart' (Deutschland, 8th edn, 1858). By the mid-19th century, a whole industry of travel agents, guidebooks, tour operators, hotels, and railways had sprung up to cater to these new travellers. Baedeker was by no means the only name around: other notables included Byron's publisher, John Murray, who was to fight a losing battle with Baedeker through the 19th century for the guidebook market, and Thomas Cook, the travel agent. Steam-driven ships linked Dover and Calais in 1821, and steamers began to ply the waters of the Rhine, Rhône, and Danube a few years later. And when the railways appeared 20 years later, the entire communications network of modern tourism was in place.

Hundreds of volumes had been published by enterprising travellers and publishers in the era of the Grand Tour. But by definition, these books were idiosyncratic and tendentious, like Tobias Smollett's badtempered account of his travels in France and Italy, or its successor Sterne's $A$ Sentimental Journey, which although a highly entertaining read is entirely useless as a guidebook. People on the Grand Tour had their servants to arrange things, and letters of introduction to other people whose servants would also arrange things. Murray and Baedeker, recognising a new market, produced distinctive standardised guidebooks designed to fit in the hand or travelling bag $(16 \times 11 \mathrm{~cm})$ : they were regularly updated, used a star system to rank sights, advised on tipping and other traps for the unwary ('A porter in Mannheim should receive 12 kreuzer for carrying a trunk weighing more than 40 pounds, 8 kreuzer for one weighing less'), and generally allowed the tourist to dispense with actual human guides, who wanted their groschen too. Baedeker's thrift was proverbial; and grateful tourists wrote to him from all over Europe to thank him for protecting the virtue of their wallets.

Emulated by many other guidebooks (and not just guidebooks) since, the star system shaped the notion that there was a traveller's canon of sights that, come what may, had to be seen. Not everybody agreed with the canon, however. Throughout Baedeker's lifetime, Mont Blanc earned no stars at all: 'The view from the summit is unsatisfactory'. Karl Baedeker was almost excruciatingly thorough, absolutely convinced of his own rectitude (an opinion evidently shared by his readers), and in the habit of visiting hotels incognito. He had the reputation of never recommending a hotel unless he had seen it first. Soon he was owning up to being not just the publisher of, but the main researcher for his books too, 'The entire contents of the book are based exclusively on personal experience'. So popular were his books, and such was his reputation for reliability that the German Kaiser Wilhelm was reputed to have stationed himself at a particular palace window at noon because, 'It's written in Baedeker that I watch the changing of the guard from that window, and the people have come to expect it'.

After Baedeker's death in 1859 his empire passed to his three sons, and the authority of the founder gave way to editorial bureaucracy. French and English translations appeared, and by 1880 Baedeker - much to the chagrin of Murray - had become the eponym for the continental guidebook. In 1872 the firm moved to Leipzig, the capital of German publishing. Every few years it would issue a new handbook, each surveying some vast new region of the globe: Palestine and Syria 1875, Lower Egypt 1877, Sweden and Norway 1879, Russia 1883, France 1884-1885, Great Britain 1887, Upper Egypt 1891, US 1893, and so on, arriving with a guide to India on the dawn of the First World War in 1914. Like many German firms, its patriotism got the better of it, and it found itself in even worse company after 1933 (the term used for Hermann Goering's bombing missions to flatten some of the culturally significant towns in the UK was 'Baedeker raids'). The firm was able to resume publishing again in 1948, but never again enjoyed the same universal reputation for reliability and probity. The market had changed; and the world too. The confidence and fixed world view of the 19th century had gone, along with the rhetorical device known as the Baedeker parenthesis - bracketing without ironic intent an item of practical information ('small gratuity') inside a poetic description. No longer were guidebooks a matter of the autonomous traveller out in the world, casting a strategic eye on the Alpine landscapes and the churches with stars and the people who served; in his or her place was the observer caught up in the act of observation. The next line of successful guidebooks made its name by suggesting that the planet itself was lonely, a conceit that would have been utterly opaque to Karl Baedeker.

\section{lain Bamforth}

\section{FURTHER READING}

Second-hand copies of Baedeker's guides can be found in good antiquarian bookstores everywhere: some are collector's items (such as the 1934 German-language guide to Madeira and some of the early volumes by Karl Baedeker), but the mass-produced, revised editions (such as Switzerland and Northern Italy) are frequent, inexpensive, and have splendid folding maps of cities, mountain ranges, glaciers, and other natural and cultural wonders.

Parson N. Worth the detour: a history of the guidebook. Stroud: Sutton, 2007

\section{DOI: 10.3399/bjgp10X544825}

